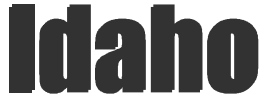
Completion Project

Bechtel BWXT Idaho, LLC
ICP/CON-04-00640

PREPRINT

Drop Testing Of DOE Spent Nuclear Fuel Canisters

\author{
Spencer D. Snow \\ D. Keith Morton \\ Tommy E. Rahl \\ Robert K. Blandford \\ Thomas J. Hill
}

July $17-21,2005$

\section{ASME Pressure Vessels and Piping Division Conference}

This is a preprint of a paper intended for publication in a journal or proceedings. Since changes may be made before publication, this preprint should not be cited or reproduced without permission of the author.

This document was prepared as a account of work sponsored by an agency of the United States Government. Neither the United States Government nor any agency thereof, or any of their employees, makes any warranty, expressed or implied, or assumes any legal liability or responsibility for any third party's use, or the results of such use, of any information, apparatus, product or process disclosed in this report, or represents that its use by such third party would not infringe privately owned rights. The views expressed in this paper are not necessarily those of the U.S. Government or the sponsoring agency. 


\title{
DROP TESTING OF DOE SPENT NUCLEAR FUEL CANISTERS ${ }^{1}$
}

\author{
Spencer D. Snow \\ D. Keith Morton, Tommy E. Rahl, Robert K. Blandford, Thomas J. Hill \\ Idaho National Laboratory \\ P.O. Box 1625 \\ Idaho Falls, Idaho 83415-3760 \\ United States of America \\ (208) 526-8510, (208) 526-4313, Spencer.Snow@inl.gov
}

\begin{abstract}
The National Spent Nuclear Fuel Program (NSNFP) at the Idaho National Engineering and Environmental Laboratory (INEEL) prepared four representative Department of Energy (DOE) spent nuclear fuel (SNF) canisters for the purpose of drop testing. The first two canisters represented a modified 24inch diameter standardized DOE SNF canister and the second two canisters represented the Hanford Multi-Canister Overpack (MCO). The modified canisters and internals were constructed and assembled at the INEEL. The MCO internal weights were fabricated at the INEEL and assembled into two MCOs at Hanford and later shipped to the INEEL for drop test preparation. Drop testing of these four canisters was completed in August 2004 at Sandia National Laboratories. The modified canisters were dropped from 30 feet onto a flat, essentially unyielding surface, with the canisters oriented at 45 degrees and 70 degrees off-vertical at impact. One representative $\mathrm{MCO}$ was dropped from 23 feet onto the same flat surface, oriented vertically at impact. The second representative MCO was dropped onto the flat surface from 2 feet oriented at 60 degrees off-vertical. These drop heights and orientations were chosen to meet or exceed the Yucca Mountain repository drop criteria. This paper discusses the comparison of deformations between the actual dropped canisters and those predicted by pre-drop and limited post-drop finite element evaluations performed using ABAQUS/Explicit. Post-drop containment of all four canisters, demonstrated by way of helium leak testing, is also discussed.
\end{abstract}

\section{INTRODUCTION}

The mission of the National Spent Nuclear Fuel Program (NSNFP) is to help Department of Energy (DOE) sites safely dispose of their spent nuclear fuel (SNF) at the nation's repository, currently designated as Yucca Mountain. To achieve this goal, the NSNFP has taken steps to support those sites with existing canister designs [e.g., Hanford's MultiCanister Overpack (MCO)] by helping to gain repository acceptance of those canister designs or to develop a new canister specifically designed for interim storage, transportation to the repository, and for disposal at the repository without having to reopen that canister.

The NSNFP first funded a demonstration drop testing effort for the standardized DOE SNF canister in 1999 [1]. A major goal of that drop testing effort was to demonstrate the robust design of the 18-inch standardized DOE SNF canister and to demonstrate the canister's ability to maintain containment after an accidental drop event. At that time, the 18-inch diameter standardized DOE SNF canister was the only size anticipated to be used by the DOE SNF sites, with the exception of the MCO at Hanford. That drop testing effort helped gain repository acceptance of the standardized DOE SNF canister design.

Since the completion of the 1999 drop testing effort, the repository has altered its surface facility design concept to rely on DOE SNF canisters (both standardized DOE SNF canisters and $\mathrm{MCO}$ canisters) to not breach during an accidental drop event. This change places the DOE SNF canisters on the list of components required to perform a safety function at the

\footnotetext{
${ }^{1}$ Work supported by the U. S. Department of Energy, Office of Environmental Management (National Spent Nuclear Fuel Program at the Idaho National Engineering and Environmental Laboratory) under DOE Idaho Operations Office Contract No. DE-AC07-99ID13727.
} 
repository surface facility, where incoming commercial DOE SNF are to be loaded into repository waste packages. This designation places additional significance on drop testing representative examples of all the DOE SNF canisters to determine their ability to withstand a severe accident load and still perform their containment function. In addition, the use of a modified version of the 24-inch standardized DOE SNF canister has been identified. Therefore, during 2004 and 2005, the NSNFP funded a drop testing effort to evaluate the performance of the modified version of the 24-inch standardized DOE SNF canister and the MCO.

\section{MODIFIED STANDARDIZED DOE SNF TEST CANISTER DESIGN}

Basic features of the modified 24-inch diameter standardized DOE SNF test canisters, hereafter referred to as the "modified 24-inch test canister," are as follows:

- 24-inch outer diameter canister, 15 feet in overall length, about 10,000 pounds test weight,

- Main shell and skirts made of 24-inch nominal outer diameter pipe, 1/2-inch nominal thickness, [SA-312 type 316/316L stainless steel (SST)],

- Heads flanged and dished, 3/4-inch nominal thickness, with a 2-inch long straight flange, later machined to 1/2inch thickness after skirt is attached, (SA-240 type 316/316L SST),

- Lifting rings with a 22-7/8-inch outer diameter by 20-3/4inch inner diameter made of $1 / 2$-inch thick plate, (SA-240 type 316/316L SST),

- Interior impact plates, made of 2-inch plate, (SA-36), flat on one side for the internal components to rest on and contoured on the other side to match the geometry of the inside surface of the head, held in place by retaining rings welded to the inside of each head.

- Internal bottom spacer made of a 24-inch long, 20-inch pipe (Sch. 60, SA-106 Gr. B) with two 22-inch diameter end plates (1-inch thick, SA-36), rests on the bottom impact plate,

- Internal spoked-wheel basket made of a 116-3/4-inch long, 8 -inch pipe (Sch. 100, SA-106 Gr. B) with six 1/2-inch thick, 7-inch wide full-length spokes (SA-36), rests on the bottom spacer,

- Total of 210 lengths of \#8 rebar, 116-inches long, placed in the spoked-wheel basket,

- Shield plug made of 5-3/4-inch thick, 22-7/8-inch diameter bar (AISI 1045) with an attached 10-1/4-inch length of 20inch pipe (Sch. 60, SA-106 Gr. B), rests on the spokedwheel basket.

Figure 1 shows the basic test canister configuration, and Fig. 2 shows the internal components (less rebar). These modified 24-inch test canisters and internals were fabricated at the INEEL.

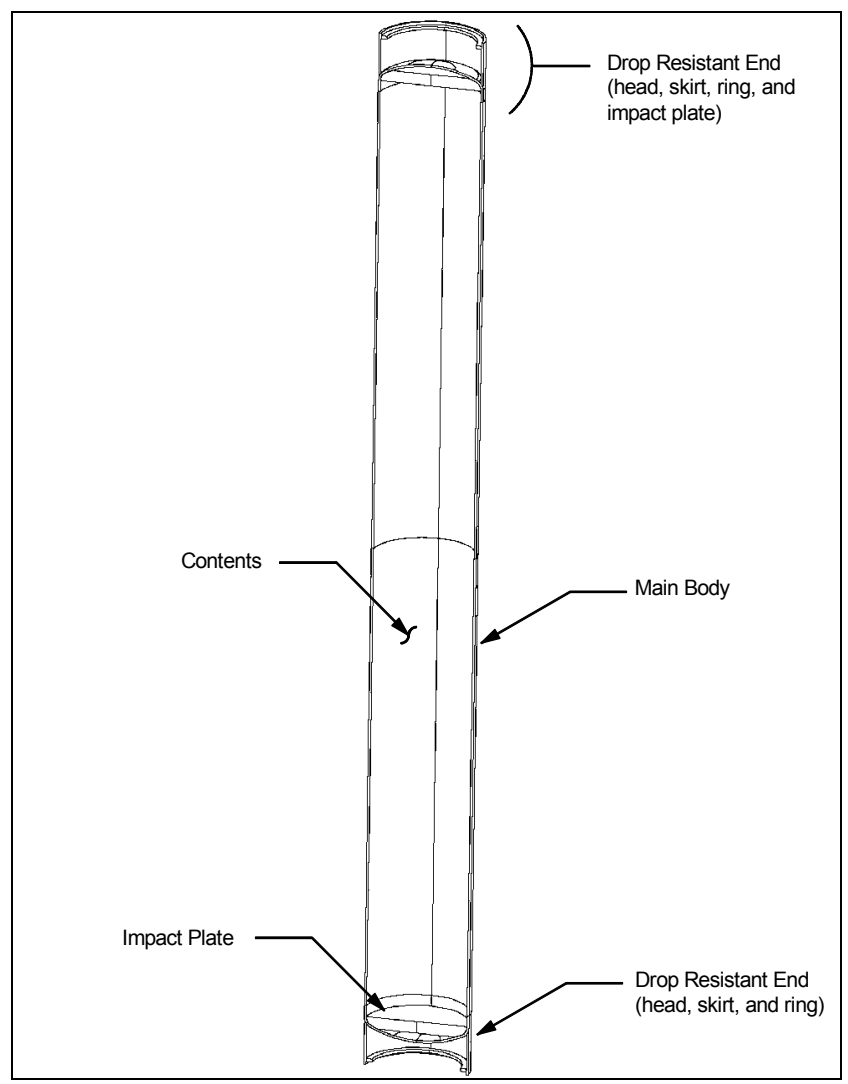

Figure 1. Modified 24-Inch Test Canister (Half-Canister Section View)

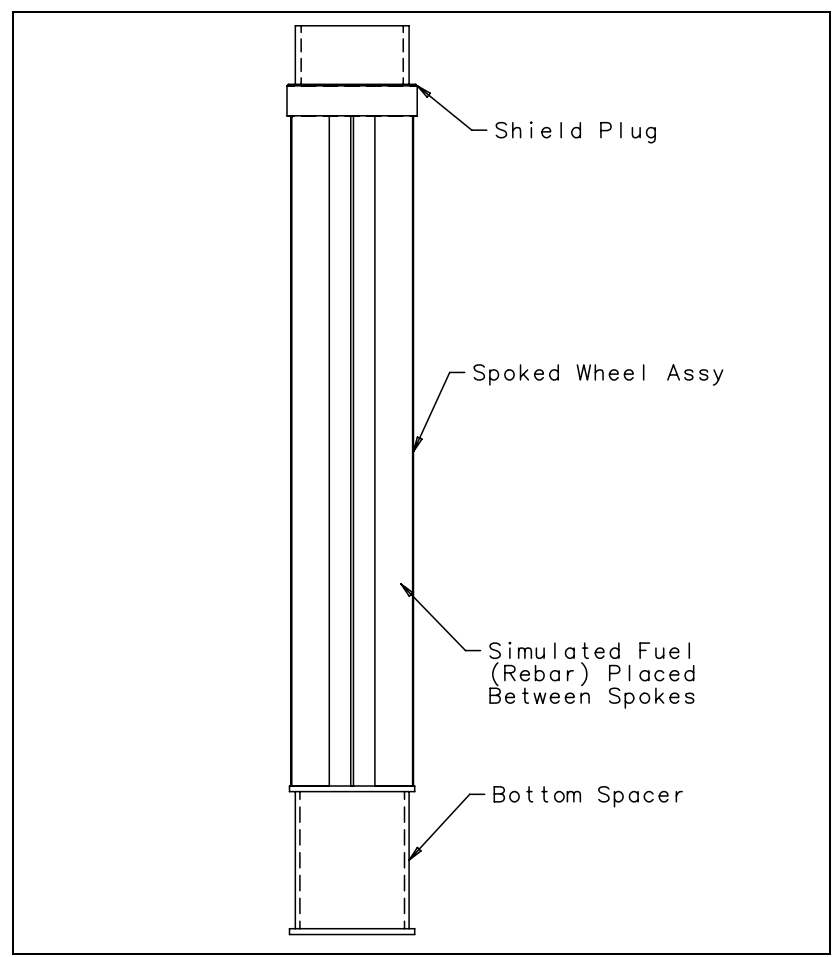

Figure 2. Modified 24-Inch Test Canister Internals 


\section{TEST MCO DESIGN}

The main components of the test MCOs were as follows:

- 24-inch nominal outer diameter canister, about 166 inches in overall length, with a test weight of about 18,000 pounds,

- Main shell made of 24-inch diameter pipe with a 1/2-inch nominal thickness (SA-312 TP304/304L SST),

- Shell bottom approximately 24 inches in diameter and 2 inches thick (SA-182 F304/304L SST),

- Collar about 15-inches in height continued from the main shell, with an increased outer diameter of 25.3 inches, threaded to accept the locking ring (SA-182 F304/304L SST),

- Shield plug assembly of about 16 inches in height (SA-182 F304L and SA-240 304L),

- Locking ring of about 6-1/2 inches in height, threaded into the collar over the shield plug (SA-182 F304N SST),

- Closure cover of about 9 inches in height welded to the collar to seal the container (SA-182 F304L),

- Four internal baskets consisting of stripped Mark IV scrap baskets (base plate and center post only, 304L SST) each with a 22-inch diameter bar [carbon steel, (CS)], 26-inches long, with a center hole to fit over the center post,

- One internal basket consisting of a representative Mark IV fuel basket with 54 bars (CS), 2-1/2-inch diameter, 22inches or 26-inches long,

Figure 3 shows the test MCO design and Fig. 4 shows the Mark IV fuel basket. The test MCOs and baskets were assembled at Hanford using the internal weights (22-inch and 2-1/2-inch diameter bars discussed above) that were fabricated at the INEEL.

\section{DROP TESTING CONDITIONS}

The drop testing was performed in August 2004 at Sandia National Laboratory (SNL). The impact surface at SNL was a 2-inch thick steel armor plate grouted and anchor bolted to a heavily reinforced concrete block that weighed about 462,000 pounds. This was more than 25 times heavier than the test canisters and was considered essentially unyielding.

The test canisters were to be dropped from various heights and angles to meet specific project goals. Table 1 shows the test canister identifier. This identifier lists the test canister first (24MOD for the modified 24-inch test canister, MCO for the test MCOs), followed by the intended drop angle from vertical, and ending with a unique numerical identifier (1 or 2). Table 1 also shows the actual loaded weight for a test canister, the drop height, and the desired impact angle.

Figure 5 shows the internal loading configuration of test MCO-00-1 and Fig. 6 shows the same for test MCO-60-2. Figures 7 and 8 show the test canisters prior to their being shipped to SNL.

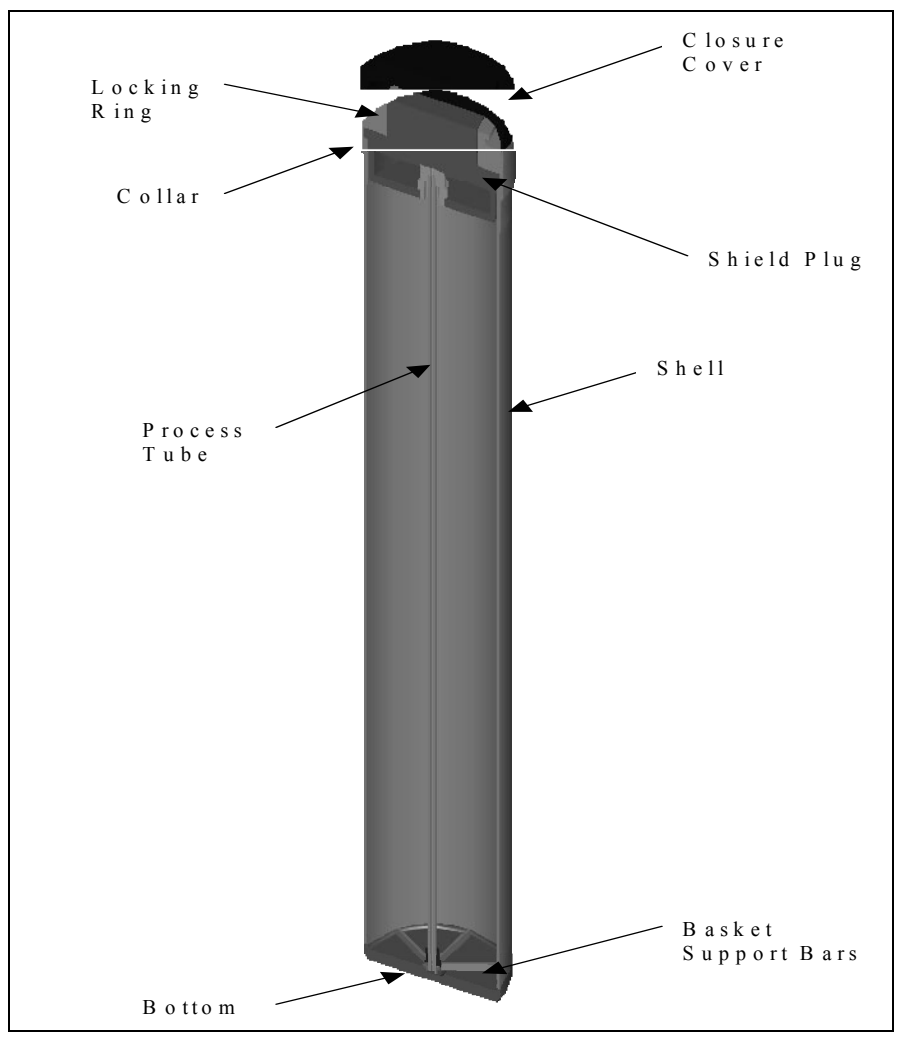

Figure 3. Test MCO (Half-Canister Section View))

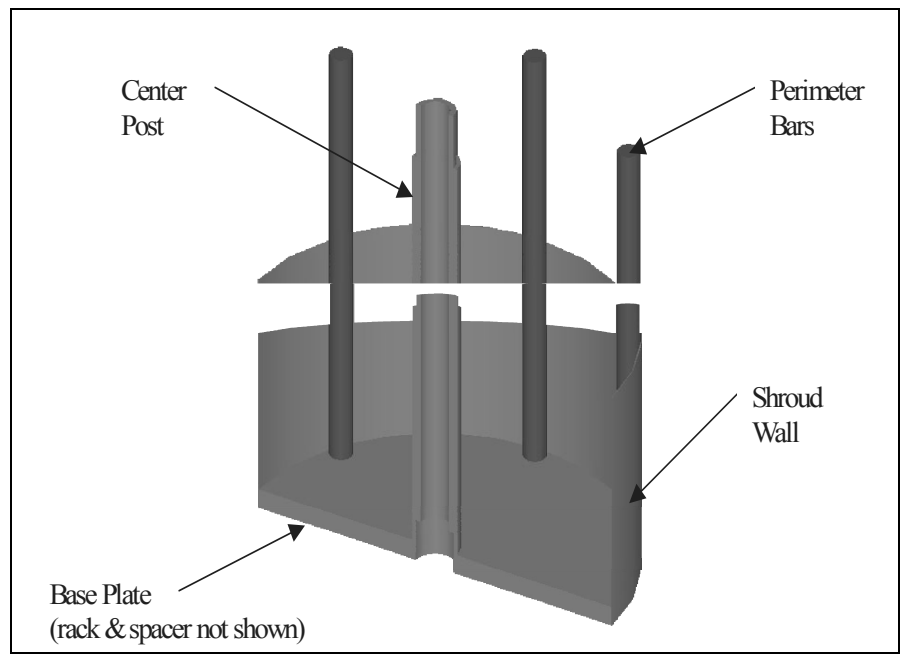

Figure 4. Test MCO Mark IV Fuel Basket (Half-Basket Section View)

Table 1. Test Canister Drop Details

\begin{tabular}{|l|c|c|c|}
\hline $\begin{array}{c}\text { Canister } \\
\text { Identifier }\end{array}$ & $\begin{array}{c}\text { Test Weight } \\
\text { (lbs) }\end{array}$ & $\begin{array}{c}\text { Drop Height } \\
\text { (ft.) }\end{array}$ & $\begin{array}{c}\text { Impact } \\
\text { Angle } \\
\text { ( } \text { from } \\
\text { vertical) }\end{array}$ \\
\hline 24MOD-45-1 & 10,010 & 30 & 45 \\
\hline 24MOD-70-2 & 10,027 & 30 & 70 \\
\hline MCO-00-1 & 17,784 & 23 & 0 \\
\hline MCO-60-2 & 18,247 & 2 & 60 \\
\hline
\end{tabular}




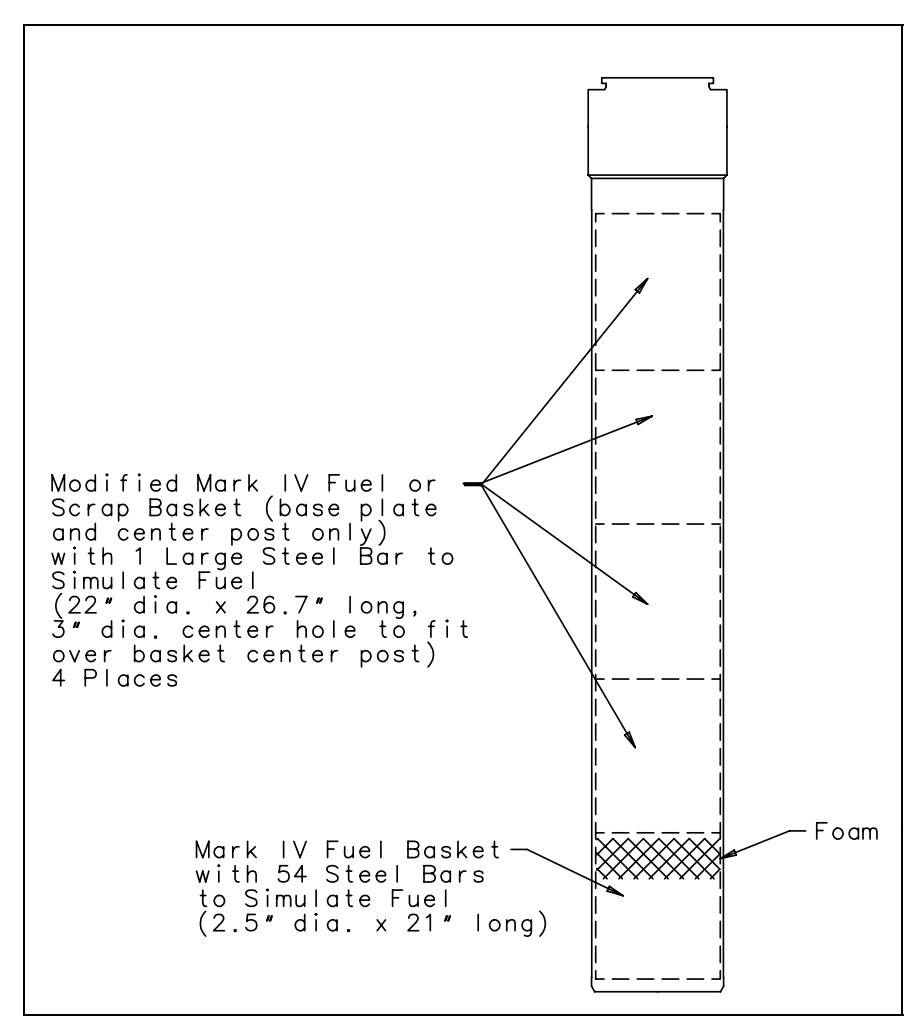

Figure 5. MCO-00-1 Loading Sketch

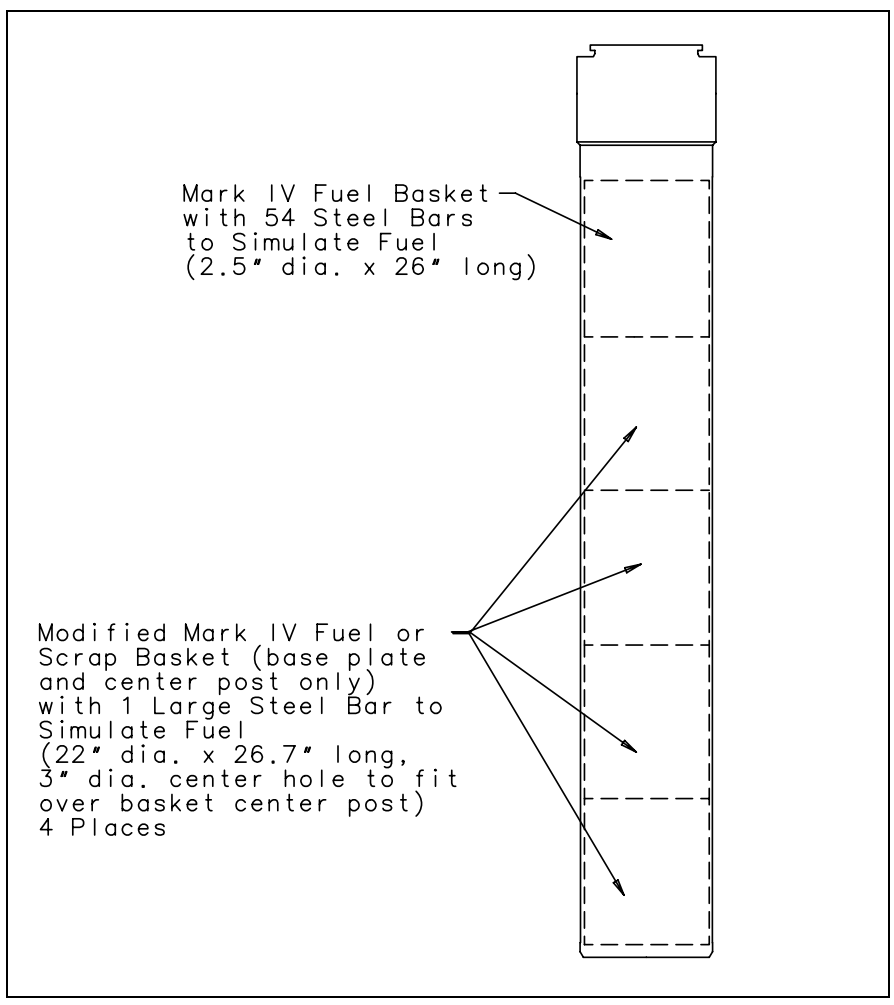

Figure 6. MCO-60-2 Loading Sketch

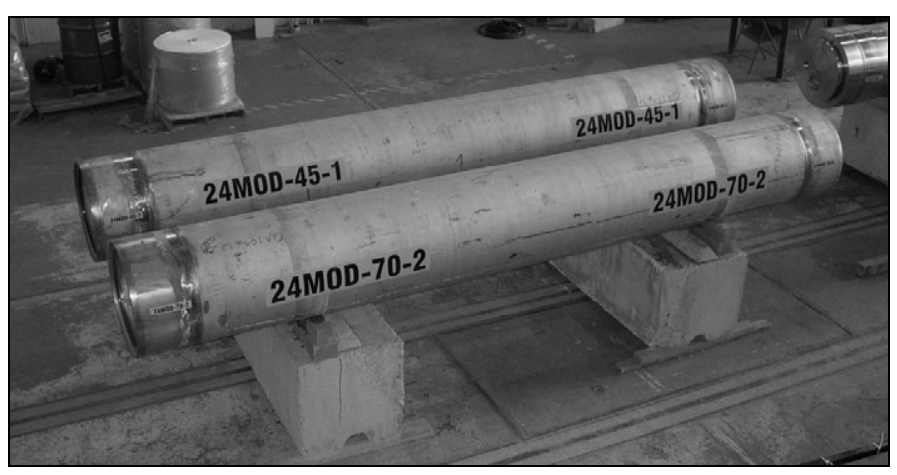

Figure 7. Modified 24-Inch Test Canisters

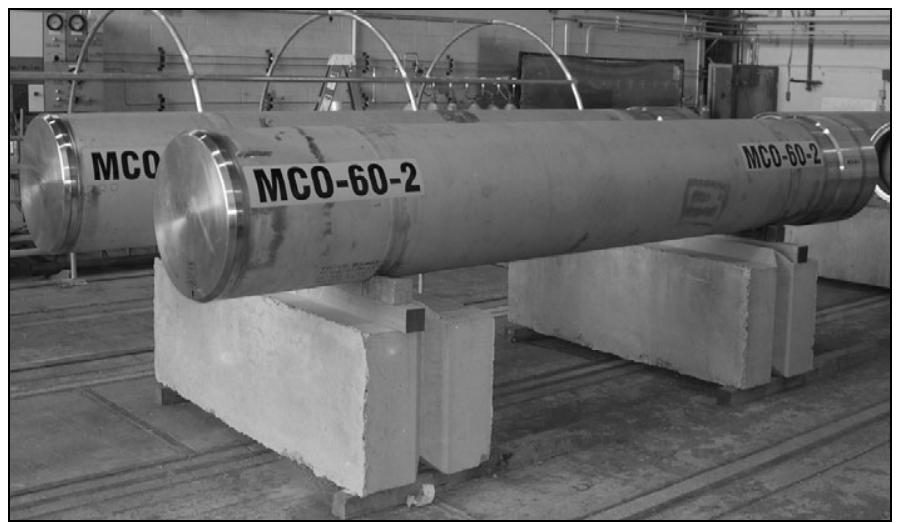

Figure 8. Test MCOs

\section{COMPUTER MODELING}

Finite element (FE) models of the four test canisters were created using the I-DEAS modeling software [2]. The FE models were then exported to a format compatible for a solution using ABAQUS/Explicit Version 6.3-3 [3].

The test canisters were modeled using solid linear brick elements (ABAQUS element type C3D8R), wedge elements (ABAQUS element type C3D6), and shell elements (ABAQUS element type S4R). The flat impact surface was represented with a rigid element (ABAQUS type R3D4) fixed in space. About 29,000 elements were employed in representing each modified 24-inch test canisters, and about 36,000 elements represented each test MCOs.

Because of symmetry in modeled geometry, loading, and expected response of these test canisters, one plane of symmetry was employed. Therefore, only half of a test canister was required in the FE models.

Contact between components was simulated using the ABAQUS General Contact option, supplemented by the Contact Pairs option in areas of interest (e.g., impact locations). A coefficient of friction of 0.3 was employed for all contact in the models [4].

True stress-strain curves were obtained for the containment boundary materials of these test canisters. The stress in each curve was then increased by $20 \%$ to account for the dynamic strengthening that was expected during the drop 
testing. This was consistent with the 1999 testing and analysis program [1] and is further justified by current data being presented at this conference [5].

Figures 9 and 10 show the FE models for these test canisters.

\section{DROP TEST RESULTS VS. MODEL PREDICTIONS}

\section{Deformations}

Test 24MOD-45-1: Significant deformations occurred in this test canister due to the 30 -foot (45 degrees off-vertical) drop event. Most of the deformations occurred in the skirtedends of this canister - as designed, with minimal containment component (heads, main shell) deformations. Figure 11 shows a side view of the actual deformed bottom of modified 24-inch test canister 24MOD-45-1, and Fig. 12 shows the FE model predicted shape. Figures 13 and 14 show an end view of that same canister bottom. The figures show that the modelpredicted deformations matched closely to those of the actual test canister 24MOD-45-1. Though not shown in this paper, the deformations at the top end also compared well. Typical dimensional comparisons were within $4 \%$.

Test 24MOD-70-2: Significant deformations occurred in this test canister due to the 30 -foot ( 70 degrees off-vertical) drop event. Most of the deformations occurred in the skirtedends of this canister - as designed. However, because the impact angle was closer to horizontal than test canister 24MOD-45-1, this canister experienced some deformations in the containment boundary components. Figure 15 shows a side view of the actual deformed bottom of modified 24-inch test canister 24MOD-70-2, and Fig. 16 shows the FE model predicted shape. Figures 17 and 18 show an end view of that same canister bottom. The figures show that the modelpredicted deformations matched closely to those of the actual test canister 24MOD-70-2. Though not shown in this paper, the deformations at the top end also compared well. Typical dimensional comparisons were within $3 \%$.

Test MCO-00-1: Very small ( $<1 / 4-$ inch) deformations occurred in this test MCO-00-1 due to the 23-foot, vertical drop event. This test MCO remained vertical after the drop test. Figure 19 shows a side view of the actual test MCO deformed bottom and Fig. 20 shows the FE model predicted deformation. Because the deformations were so small, Fig. 19 and Fig. 20 appear to show no deformation to MCO-00-1. Actual and modeled changes in diameters were within $1 \%$.

However, the interesting deformations in this test MCO-00-1 occurred in the bottom internal basket. The drop energy of the internals (baskets and simulated SNF) was almost entirely absorbed by plastic deformation in this bottom basket. Figure 21 shows the deformed bottom basket (without the simulated SNF) after it was removed from the dropped test MCO-00-1. Figure 22 shows the FE-calculated deformations to the bottom basket from a whole model (post-drop model, no plane of symmetry used).

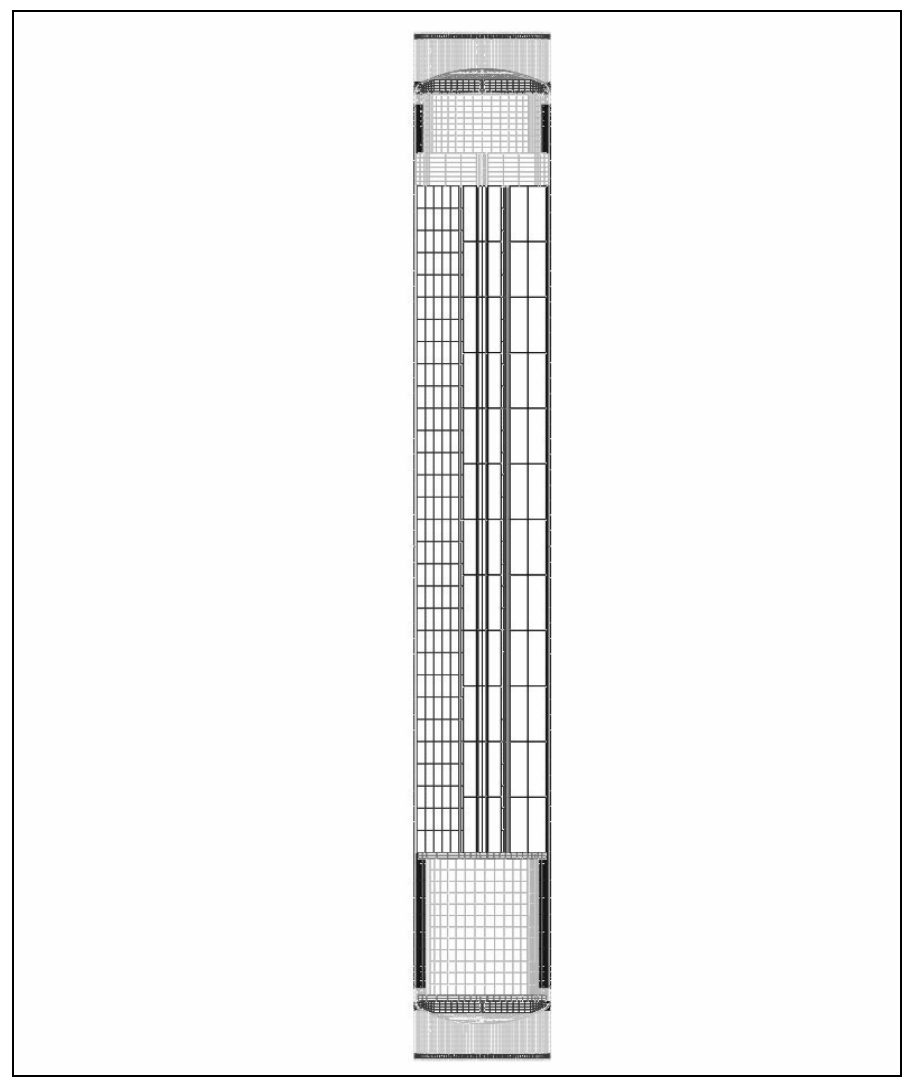

Figure 9. Modified 24-Inch Test Canister FE Model

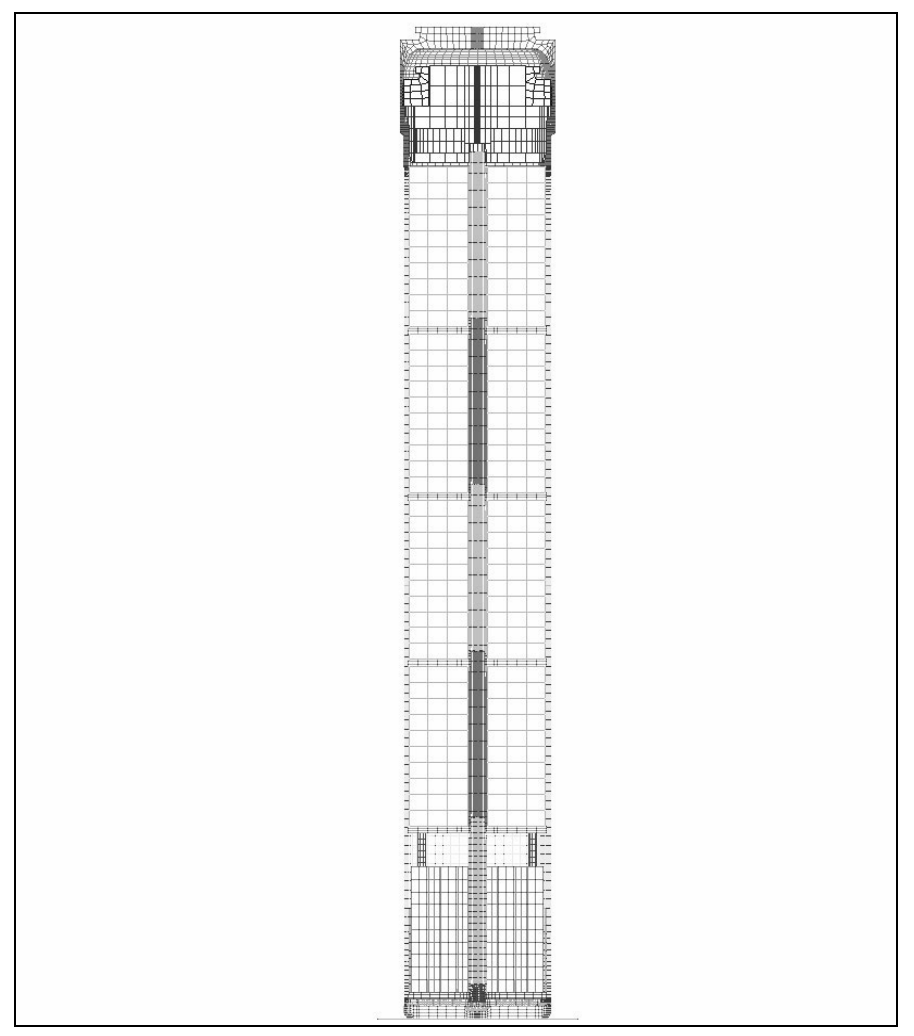

Figure 10. Test MCO FE Model 


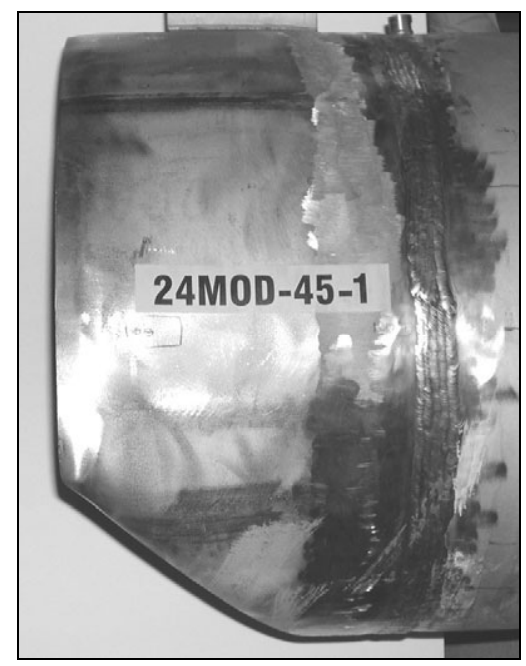

Figure 11. Photo of Test Canister 24MOD-45-1 Bottom End Deformed Shape, Side View

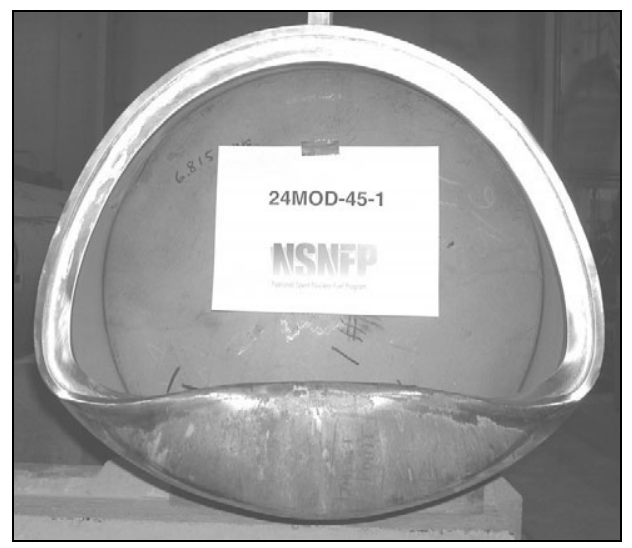

Figure 13. Photo of Test Canister 24MOD-45-1 Bottom End Deformed Shape, End View

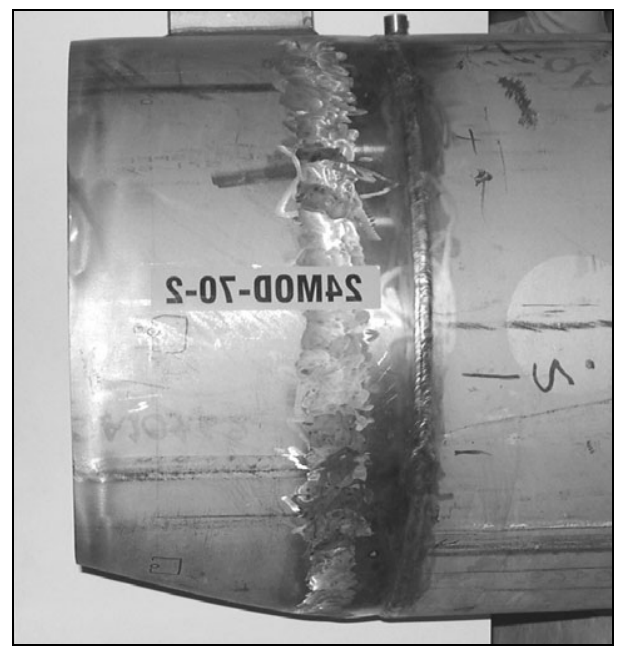

Figure 15. Photo of Test Canister 24MOD-70-2 Bottom End Deformed Shape, Side View (Photo Reversed)

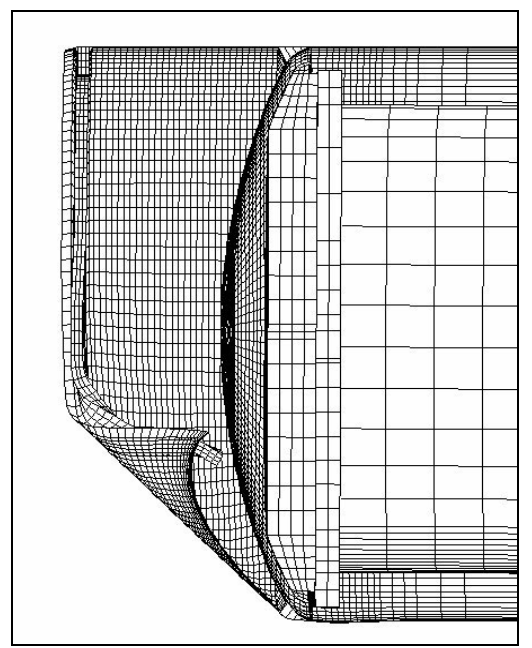

Figure 12. Pre-Drop Model 24MOD-45-1 Bottom End Deformed Shape, Side View

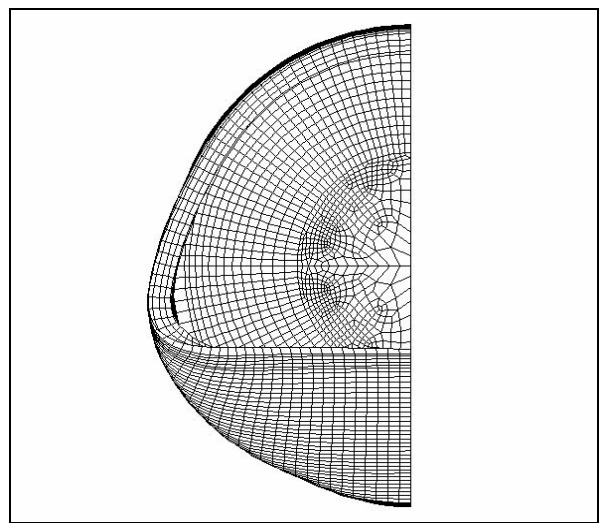

Figure 14. Pre-Drop Model 24MOD-45-1 Bottom End Deformed Shape, End View

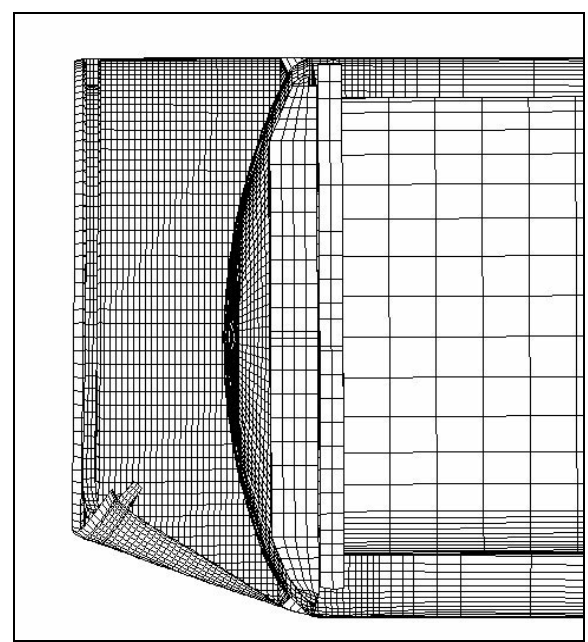

Figure 16. Pre-Drop Model 24MOD-70-2 Bottom End Deformed Shape, Side View 


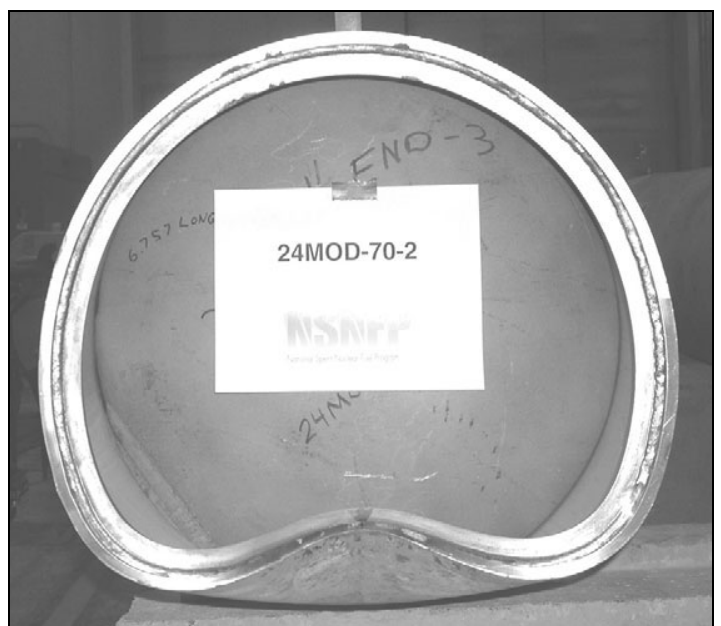

Figure 17. Photo of Test Canister 24MOD-70-2 Bottom End Deformed Shape, End View

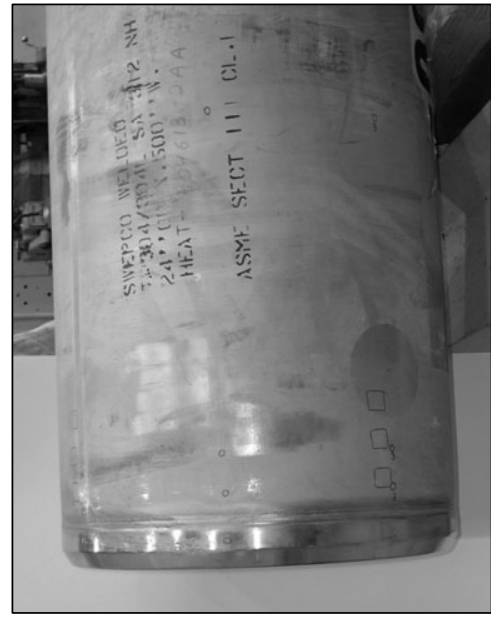

Figure 19. Photo of Test MCO-00-1 Bottom End Deformed Shape, Side View

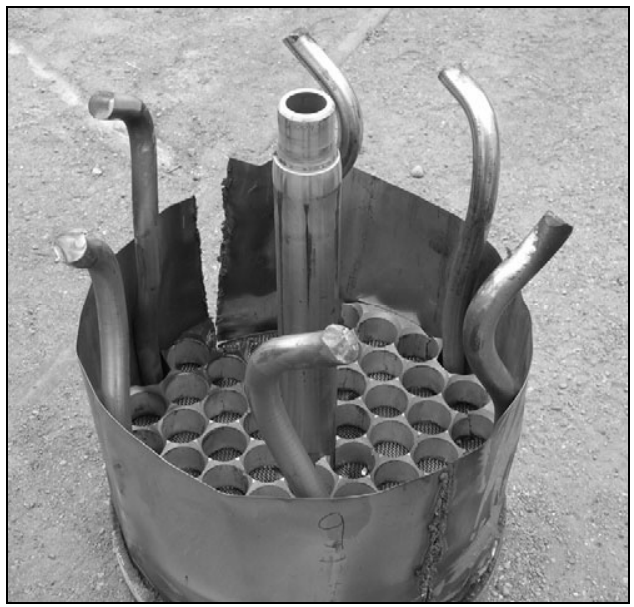

Figure 21. Test MCO-00-1 Bottom Basket Deformations

(Cuts on basket wall not due to drop testing, but resulted from main shell post-drop longitudinal cutting operations.)

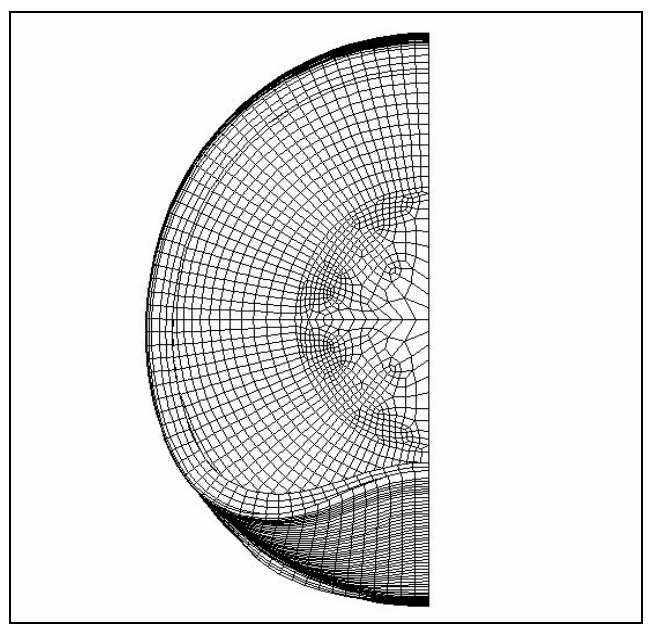

Figure 18. Pre-Drop Model 24MOD-70-2 Bottom End Deformed Shape, End View

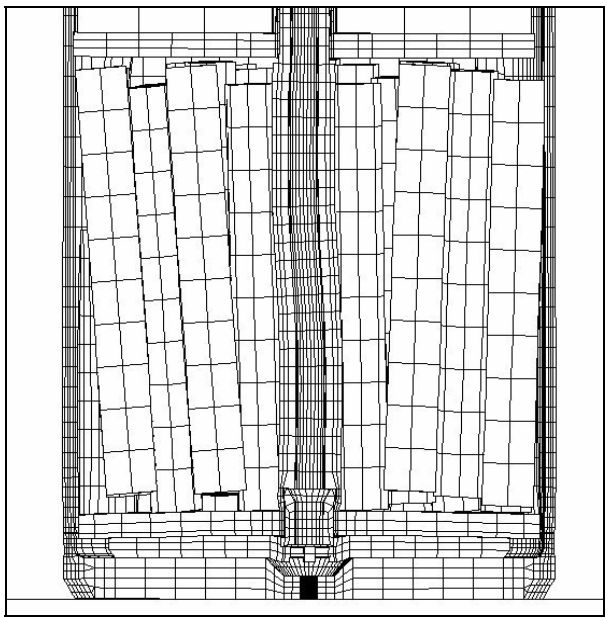

Figure 20. Pre-Drop Test MCO-00-1 Model Bottom End Deformed Shape, Side View

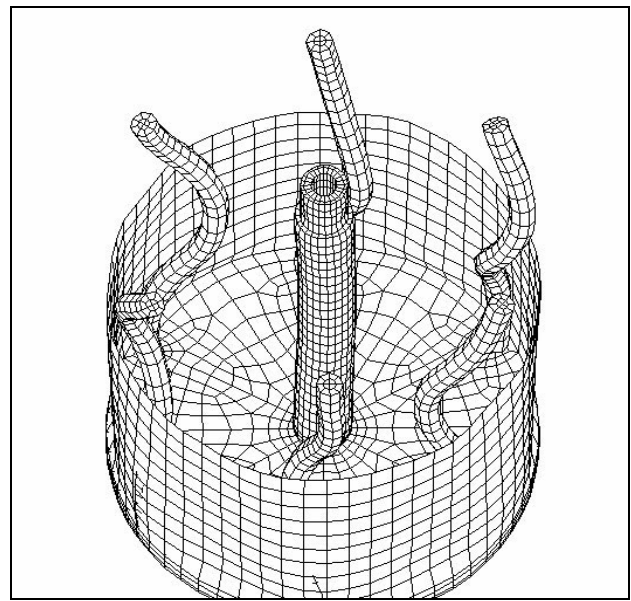

Figure 22. Post-Drop Whole Model of Test MCO-00-1 Bottom Basket Deformations 


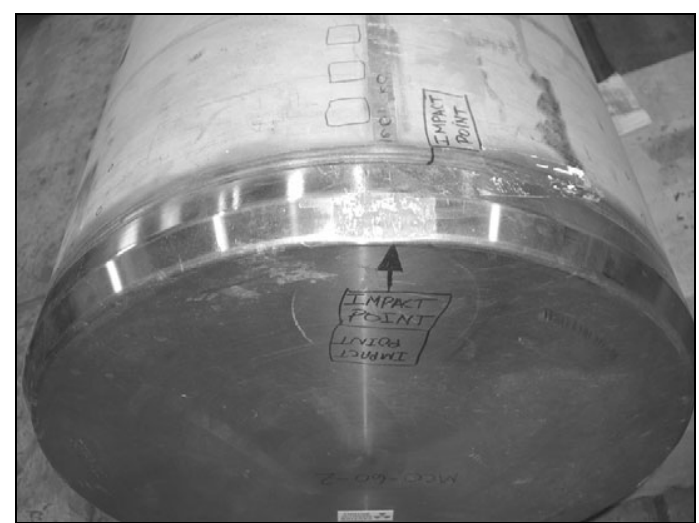

Figure 23. Photo of Test MCO-60-2 Bottom End at First Impact Location

Test MCO-60-2: Test MCO-60-2 was dropped from 2 feet onto the rigid surface, impacting at an angle of 60 degrees off-vertical. Because of the low drop height (and resulting low drop energy), the deformations to the test MCO were limited to minor scuffing and flattening in the area of the first impact (on the bottom edge as shown in Fig. 23) and the second impact (near the top - not shown herein). The FE model deformations were equally hard to see. Figure 24 shows the pre-drop FE model strain contour (in grayscale) simply to show where the slight deformations occurred. Actual and model changes in diameters were within $1 \%$.

\section{Strains}

Surface strains due to the drop event were measured on the actual canisters at a small number of locations only. Those strains agreed with those predicted in the FE models. The following summarizes the pre-drop predicted peak strains in the test canisters.

Test 24MOD-45-1: The pre-drop predicted peak equivalent plastic strains (PEEQ) in the containment components occurred in the head, with a maximum surface strain of $26.4 \%$ and a maximum mid-plane strain of $9.3 \%$. The maximum surface PEEQ strain in the skirts, where the bulk of the drop energy was absorbed, was $49.5 \%$. Rupture of the containment boundary was not predicted in this test canister.

Test 24MOD-70-2: The pre-drop predicted PEEQ strains in the containment components occurred in the head, with a maximum surface strain of $51.9 \%$ and maximum mid-plane strain of $14.9 \%$. The maximum surface PEEQ strain in the skirts, where a significant portion of the drop energy was absorbed, was $45.5 \%$. Rupture of the containment boundary was not predicted in this test canister.

Test MCO-00-1: The pre-drop predicted PEEQ strains in the containment components occurred in the MCO bottom, with a maximum surface strain of $3.5 \%$ and a maximum midplane strain of $2.9 \%$. Rupture of the containment boundary was not predicted in this test MCO.

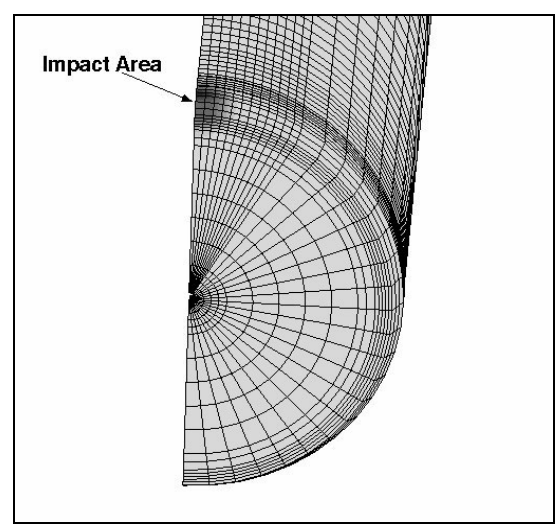

Figure 24. Pre-Drop Test MCO-60-2 Model Bottom End at First Impact Location, Strains

Test MCO-60-2: The pre-drop predicted PEEQ strains in the containment components occurred in the MCO bottom, with a maximum surface strain of $20 \%$ and a maximum midplane strain of 7\%. Rupture of the containment boundary was not predicted in this test MCO.

\section{Leak Tightness}

Helium leak testing per ASME Section V requirements (using a Hood Method) demonstrated that test canisters 24MOD-45-1, 24MOD-70-2, and MCO-60-2 had post-drop leak rates that were less than $1 \times 10^{-7} \mathrm{std} \mathrm{cc} / \mathrm{sec}$, and were, therefore, "leaktight" as defined in ANSI N14.5 [6]. Due to helium leak testing performed by Hanford during test MCO assembly, the helium background in test MCO-00-1 was too high to successfully employ a Hood Method helium leak test. However, test MCO-00-1 was shown (using a Detector Probe Method) to have a leak rate of not greater than $1 \times 10^{-5} \mathrm{std}$ $\mathrm{cc} / \mathrm{sec}$.

\section{CONCLUSIONS}

Two test canisters representing the modified 24-inch standardized DOE SNF canister and two test canisters representing the MCO were drop-tested. Post-drop helium leak testing showed that no containment ruptures occurred in the test canisters. FE modeling of the drop events accurately predicted the actual deformation experienced by the test canisters.

\section{REFERENCES}

[1] Snow, S. D., Morton, D. K., Rahl, T. E., Ware, A. G., and Smith, N. L., 2000, “Analytical Evaluation of Drop Tests Performed on Nine 18-Inch Diameter DOE Spent Nuclear Fuel Canisters," ASME PVP, 408, pp. 97 - 106.

[2] I-DEAS 10 NX Series, 2002, Unigraphics Solutions, Inc., Electronic Data Systems Corp.

[3] ABAQUS/Explicit Version 6.3-3, 2002, ABAQUS, Inc. 
[4] Snow, S. D., Morton, D. K., Rahl, T. E., and Ware, A. G., 2001, "Preliminary Drop Testing Results to Validate an Analysis Methodology for Accidental Drop Events of Containers for Radioactive Materials," ASME PVP, 425, pp. 63-68.

[5] Blandford, R. K., Morton, D. K., Rahl, T. E., and Snow, S. D., 2005, "Impact Testing of Stainless Steel Materials," ASME PVP2005-71133.

[6] American National Standards Institute, 1987, “American National Standard for Radioactive Materials - Leakage Tests on Packages for Shipment," ANSI N14.5.

\section{NOTICE}

This paper was prepared as an account of work sponsored by an agency of the U. S. Government. Neither the U. S.

Government nor any agency thereof, or any of their employees, makes any warranty, expressed or implied, or assumes any legal liability or responsibility for any third party's use, or the results of such use, of any information, apparatus, product or process disclosed in this report, or represents that its use by such third party would not infringe privately owned rights. The views expressed in this paper are not necessarily those of the U.S. DOE. 